\title{
Structural and Hydrogeological Prerequisites for Oil and Gas Potential on the Shelf of the Barents and Kara Seas
}

ISSN: 2578-0255

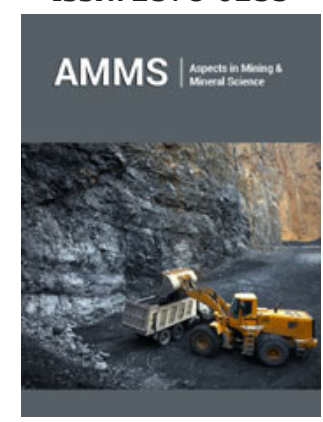

*Corresponding author: Sergey Sudarikov, Saint-Petersburg Mining University, Russia

Submission: 侮 May 12, 2020

Published: 海 September 03, 2020

Volume 5 - Issue 3

How to cite this article: Sergey Sudarikov, Sergey Vlasenko. Structural and Hydrogeological Prerequisites for Oil and Gas Potential on the Shelf of the Barents and Kara Seas. Aspects Min Miner Sci. 5(3). AMMS. 000615. 2020.

DOI: 10.31031/AMMS.2020.05.000615

Copyright@ Sergey Sudarikov, This article is distributed under the terms of the Creative Commons Attribution 4.0 International License, which permits unrestricted use and redistribution provided that the original author and source are credited.

\author{
Sergey Sudarikov* and Sergey Vlasenko
}

Saint-Petersburg Mining University, Russia

\section{Opinion}

Purpose of the investigation is to determine the factors of formation and evolution of the Barents-Kara shelf hydrogeological area and determine the prospects of oil and gas potential of submarine artesian basins. Objectives are to determine the role of latest tectonics processes in the reorganization and separation of individual basins on the shelf, the connection of highamplitude displacements of the earth's crust at the latest stage with the reorganization or destruction of hydrocarbon deposits in areas of significant movement along the latest faults, and the determination of the prospects for oil and gas potential in the Barents-Kara shelf hydrogeological region. The latest tectonics regime of the continental margin is considered as one of the important criteria for determining the prospects for oil and gas potential of artesian basins of the shelf of the Arctic Ocean and adjacent land. At the newest stage, reformation and separation of individual gas-bearing basins within the hydrogeological structures on the shelf took place. High-amplitude displacements of the Earth's crust led to an increase in the amplitudes of gas-bearing structures in some areas of the transition zone and to the reformation or destruction of hydrocarbon deposits in areas of significant movement along the latest faults. The latest tectonics regime of the Barents-Kara plate generally favored the preservation and reformation of hydrocarbon deposits and an increase in the amplitudes of oil and gas bearing structures. It is possible that a significant part of the hydrocarbons in the bowels of the plate was formed precisely in the Cenozoic era.

The identification of the patterns of formation and distribution of oil and gas accumulations in the bowels of sedimentary basins was solved using a statistical analysis of the results of seismic stratigraphic, paleotectonic, geophysical, and geochemical studies. The cartographic method is widely used in the study: the construction and analysis of maps and schemes for detailed hydrogeological and oil and gas geological zoning, tectonic, geomorphological, paleogeographic, geocryological. The tectonic regime of the continental margin is considered as one of the most important criteria for determining the prospects for oil and gas potential of artesian shelf basins and adjacent land. In the regional forecast, the most important elements are the tectonic type of the basin, the total sedimentary cover volume, the maximum thickness of sedimentary rocks, the volume of sediments deeper than $2 \mathrm{~km}$, the porosity of the section, the intensity of the Mesozoic-Cenozoic folding. Latest tectonics criteria in predicting hydrocarbon deposits are considered as essential elements of the whole complex of criteria for oil and gas potential, especially to assess the degree of preservation of hydrocarbon deposits in submarine artesian basins. Representations of the hydrogeological indicators of the oil and gas potential of the shelf of the Barents and Kara Seas, until recently, were based 
on studies of the 70's of the last century. As a result of the analysis of seismic, stratigraphic, paleotectonic, geochemical research data accumulated over recent years, it was possible to justify and conduct a hydrogeological zoning of this vast area at a modern level. At the same time, a new type of hydrogeological structure was identified that was not previously considered in regional hydrogeological constructions-the Barents-Kara shelf hydrogeological region. Within the Barents-Kara shelf hydrogeological region, submarine and seminarian (partially below sea level) artesian basins of the first order are distinguished. The distinguished shelf basins differ in a number of structural features from those distinguished earlier sub-oceanic basins, including the widespread occurrence of oil and gas structures. The formation and preservation of the latter was significantly influenced by latest tectonics processes. The structureforming latest uplifts significantly influenced the vertical and lateral migration of hydrocarbons and to a certain extent changed the initial reservoir pressure and oil composition in ancient and "young" deposits. Late Cenozoic regressions also led to a decrease in reservoir pressures, which are the cause of the release of gaseous hydrocarbons into the free phase and their migration from ancient deposits. The most intense decrease in reservoir pressure was manifested in hydraulically connected with the unloading basis of the water systems of the upper part of the sedimentary cover and favor the accumulation and conservation of hydrocarbons. Such geochemical indicators as elevated levels of chloroform bitumen A, methane, and heavy hydrocarbons in groundwater and bottom sediments indicate high prospects for local structures identified by seismic exploration, preserved at the latest stage and characterized by an increase in amplitudes. In the zones of new faults inherited from more ancient stages of development, geochemical signs of oil and gas potential indicate the destruction of ancient deposits. In other cases, the diagenetic nature of hydrocarbon accumulations or their technogenic origin is not ruled out. As highly promising areas, areas of marginal and intra-continental plates submerged at the latest stage with maximum thicknesses of the sedimentary cover, where the latest tectonics regime contributed to the preservation and reformation of hydrocarbon deposits, were distinguished. The bottom of the Pechora southern part of the Kara Sea is characterized by a direct continuation of the oil and gas-bearing land structures on the shelf. The Barents-Kara plate is a special oil and gas basin weakly connected with the mainland frame. The greatest prospects there may be associated with local uplifts complicating the bottom of the Barents-North-Kara mega trough, which, with increased thickness of the sedimentary cover, experienced a significant increase in amplitudes at the latest tectonics stage. This type of structure includes the Central Barents uplift, West Kola, Ludlovski saddles in the Barents Sea, and in the Kara-local structures that frame the Solitude trough.

The novelty of the study and the main achievements are as follows. For the first time, the existence of a new type of ocean hydrogeological structure, the Barents-Kara shelf hydrogeological region, is substantiated. It has been established that the latest tectonic uplifts have affected the vertical and lateral migration of hydrocarbons in the basins of the region, have changed the reservoir pressure and oil composition in the deposits. High prospects of the structures preserved at the latest stage are revealed. The contribution to the development of the global knowledge base of the oil and gas industry can be considered the justification of the special role of latest tectonics movements in the conservation and reformation of hydrocarbon deposits.

For possible submissions Click below: 